\title{
OBITUARY
}

\section{Boet Dommisse}

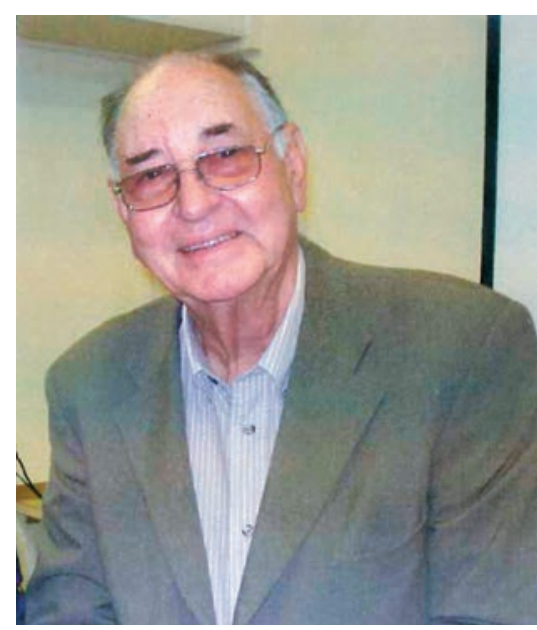

It is with great sadness that the Department of Obstetrics and Gynaecology at the University of Cape Town announces the death on 12 July 2014 of Emeritus Professor Boet Dommisse, who headed the Department from 1991 until he retired in 1996. Boet was born in Cape Town and obtained his MB ChB from UCT in 1953, the same year he married his wife Anne. They subsequently had two daughters and a son. Boet did his internship at Groote Schuur Hospital and then took a senior house officer job at the Peninsula Maternity Hospital in District Six. From 1955 to 1960 he practised as a GP in Williston and was renowned for his dedication, skill and compassion, making house calls and travelling through treacherous terrain. In 1960 he became a registrar in obstetrics and gynaecology at GSH, and in 1964 became a full-time consultant under Professor James Louw. He entered part-time private practice with Dr Cecil Craig in 1965, but remained intimately involved in teaching both underand postgraduate students at UCT/GSH. In March 1979 he returned to full-time practice at GSH and was appointed head of one of the gynaecology firms, head of the Maternity Centre and head of Undergraduate Education. He was promoted to Associate Professor in 1985 and to Deputy Head of Department in 1987.

Boet was appointed to the Chair of Obstetrics and Gynaecology at UCT following the retirement of Emeritus Professor Dennis Davey. He came to this position after some years as a consultant in the Department, during which time he was in charge of the obstetric services as head of the Maternity Centre. Those of us who worked with him each have our own memories of him, but few will dispute that he showed himself to be an intensely practical man, systematic and conscientious, well schooled in his discipline following years of private practice. These attributes alone ensured that he was widely respected by his fellow consultants in both the private and public sectors. As leader of the academic unit, he succeeded in allowing others to grow in skill and expertise without ever seeking to dominate from his position of authority. He was renowned as an outstanding teacher at both under- and postgraduate level and was a superb role model of professional, competent and compassionate patient care.

Boet was in the Chair when South Africa emerged from the era of apartheid, a time when those in leadership positions were required to take some measure of the spirit of the era, to celebrate the prevailing Zeitgeist. Boet Dommisse did not fail in this respect, institutionalising this famous moment in our collective history by putting up the new national flag in the departmental seminar room and writing beneath it in his own handwriting a sentiment expressing his commitment in terms of peace, justice and opportunity for all in the country.

Boet always had time for other people and was good at listening. He was also adept at identifying academic talent in his area of expertise, and nurturing those who subsequently went on to become international figures in obstetrics. In essence, Boet was a man of the community, for the community. He engaged with the society around him, he nurtured those who grew in his shadow, and he celebrated that which we now hold dear.

In his retirement years, he continued to do just that: he immersed himself in the history of the Simon's Town village to which he moved and, until the very end, researched, wrote about and spoke about the community of which he was a part. He was also a very accomplished photographer. He wrote a number of books, one on his experience of being a GP in a small Karoo town (under a pseudonym), and three coffee-table books on the history of Simon's Town. In doing so, he left footprints in the hearts and minds of those who remain behind. We will cherish the memory of this quietly enigmatic man, who offered so much and seemed to ask for so little.

Boet also played an influential and important role in national medical organisations. He was active in the South African Medical Association and held several positions in the South African Society of Obstetricians and Gynaecologists, of which he eventually became President. He was also elected to be the South African representative at FIGO (the International Federation of Gynecology and Obstetrics).

The Department and all who knew Boet will remember him with deep respect and love. He is survived by his wife Anne, his daughters Janette and Susan and son Jannie, and their families.

\section{Lynette Denny}

Department of Obstetrics and Gynaecology, Faculty of Health Sciences, University of Cape Town, South Africa

lynette.denny@uct.ac.za 